\title{
FROM EMERGING TO DEVELOPED MARKET: THE NEOINSTITUTIONAL APPROACH BASED ON THE CASE OF POLAND
}

\author{
Arkadiusz J. Derkacz* (D) https:(https://orcid.org/0000-0003-1363-9551
}

\begin{abstract}
Background. The issue of economic growth is still an important area of economic research. This topic is crucial for the economic sciences as well as for economic policy practice. Let this statement be the most important assumption in this article. Everything that happens in the economy concerns socio-economic phenomena. The main scientific problem comes down to the question of what is the role of institutional factors in the socio-economic development of Poland?
\end{abstract}

Research aims. The author set himself two main aims. The first aim is an attempt to present institutional determinants that affect the socio-economic development of the Polish economy. The second is an attempt to present the development of the Polish economy by setting it against the background of selected European countries.

Methodology. This work uses a modified taxonomic development measure method based on the Technique for Order Preference by Similarity to Ideal Solution (TOPSIS). The research was embedded in the current of new institutional economics. The concept of the institutional matrix was also used.

Key findings. Analyses conducted have facilitated the creation of an overview of the socio-economic development of the Polish economy. This was illustrated by the average socio-economic development index (ASEDI). Taxonomic measures of development were also calculated for all 10 of the economies analyzed. The main research time horizon is 2008-2018. Part of the collected data enabled analysis of the period 1995-2018. The results of research and analyses have shown that selected institutional factors significantly affect the final level and quality of socio-economic development of Poland in comparison with selected European countries.

Keywords: economic development, determinants of development, New Institutional Economics, Taxonomic Measure of Development, socio-economic dynamics.

JEL Codes: B520, E020, O110.

\footnotetext{
* University of Social Sciences in Warsaw, National Bank of Poland. E-mail: aderkacz@san.edu.pl.
} 


\section{INTRODUCTION}

The basic assumption of this article is that economic growth remains an important area of economic research, crucial for both the economic sciences as well as for economic policy practice. It must be emphasized as well than nothing that happens in the economy can be outside socio-economic phenomena. Economic analysis of the economy cannot be carried out without taking the social aspect into consideration. Today, many attempts are being made to stimulate national economies, which makes such analyses still valuable. They aim to show the relevant relationships and factors enabling the implementation of economic policy objectives.

This article is part of this trend. The author's scientific problem may be presented in the form of the question. What is the role of institutional factors for the socio-economic development of Poland? On this basis, two main goals presented themselves. The first is the presentation of institutional determinants that affect the socio-economic development of the Polish economy. The author proposed 89 factors that were defined as diagnostic variables. They were grouped into 8 economic phenomena. These were inscribed in three aspects / institutional perspectives. The second goal was to present the socio-economic development of the Polish economy set against the background of the economies of selected European countries: Bulgaria, the Czech Republic, France, Germany, Hungary, Lithuania, Latvia, Slovakia, and Spain. Individual national economies have been identified by their geographical/spatial economic aspects. By choosing individual countries, the author managed, above all, at showing the economic diversification of Central European countries which are still considered developing economies. The choice of Germany, France, and Spain was aimed at comparing the Polish economy to advanced and mature economies. This choice allows comparing emerging economies to developed economies. In addition, the choice of Central European countries allows comparison of the development of the Polish economy against those countries.

The previous paragraph subtly suggests the data analysis methodology used. The research is based on a modified taxonomic development measure method based on Technique for Order Preference by Similarity to Ideal Solution (TOPSIS). The research was carried out in two stages. In the first stage, potential economic phenomena 
were analyzed. They were described by means of a catalogue of diagnostic variables. Subsequently, individual geographical/spatial economic aspects were assessed. They were defined as the individual economies of 10 selected countries. In the second stage, a detailed analysis of diagnostic variables was carried out. Taxonomic development measures for individual countries were calculated on this basis. The research was conducted on the basis of data from the period 2008 to 2018. In addition, the author presented a catalogue of nine indicators, which finally became the basis for determining the average socio-economic indicator of the development of the Polish economy. On this basis, a comparative analysis was made, which made it possible to address the main issue under examination.

The analyses presented have been very much embedded in the current thinking of the new institutional economy. In addition, the institutional matrix concept was used to present a comprehensive catalogue of institutional determinants. All institutions, previously grouped in 8 economic phenomena, were embedded in three institutional perspectives. These being the economic, political, and social perspective. In this way, it was possible to draw conclusions that allowed these set goals to be achieved. It should also be mentioned that the research and analysis presented here can be the basis for further economic research. Particularly noteworthy is, e.g., the disclosed cycle of variability of the average socio-economic development index of the Polish economy or the catalogue of institutional determinants inscribed in the institutional matrix.

\section{LITERATURE REVIEW}

The contemporary economy is increasingly emphasizing the need to analyze the socio-economic activity of a man as he is. A man who operates under the influence of restrictive and enabling institutions that constitute his real living space (Coase, 1984, p. 231). This approach is characteristic primarily of the new trend in institutional economics. based on T. Veblen's statement about the institution. It is interpreted as the dominant ways of thinking, taking into account individual social conditions and specific functions of the individual and entire societies. Social institutions that guide human life are products of the past. However, they are adapted to the current 
conditions in which people function (Veblen, 2017). This statement was found in one of his most important works, which is nowadays considered to be the standard text for the development of the new institutional economics. Since then, concepts and understanding of these institutions have changed, and this has propelled economics in new directions - but not only. It should be clearly emphasized that these institutions did not exist in the socio-economic space at the time of Veblen. They have always existed (Ogilvie, 2014). They were defined and understood in different ways by economists. The development of the new institutional economics caused many of their (institutions) approaches to disappear (Coase, 1998; Hodgson, 2006; Kirdina \& Sandstrom, 2010; Kleiner, 2004; North, 2008). Nowadays, it can be said that institutions constitute a holistic sphere, which is a source of institutional determinism of human activity. Institutions, on the one hand, can enable, on the other hand, can limit this activity. Some of these institutions will be important factors, others less important determinants, which jointly condition manners of human activity in the socio-economic space.

Contemporary new institutional economics is a stream of economics that distinguishes itself from the classical economic trend. What makes it different is that it forms a very holistic anchor in its sociological aspects, with an individual economic approach to socio-economic phenomena. This means that economic considerations allow one to draw optimally objective conclusions about the way humans function in the broadly understood socio-economic environment' (Czetwertyński, 2019, pp. 165-177). In this way, the neoinstitutional trend connects the sociological, cultural, legal, geopolitical, organizational, or anthropological aspects in the context of the economic individualism of the contracting man (Obińska-Wajda, 2016, pp. 79-84). It should also be stated that the new institutional economics makes clear the dividing line between macro and microeconomics. It is not possible to analyze phenomena occurring throughout the economy, apart from the way companies operate. In turn, the analysis of the organization's operation is not complete without referring to the socio-economic environment. This character of neo-institutionalism appeared primarily in the works of Coase (1937) and Williamson (2000). In the context of the functioning of the entire economy, business management is becoming a holistic process (Stelter, 2019, pp. 73-81). Its main role has been the optimal 
allocation of resources in the manufacturing process, which ultimately determines the volume of gross domestic product (Williamson, 1985, 2002).

In this context, today, there is an ongoing talk of managing an organization in the economy, which indicates a broad subjective and objective aspect. This is revealed in the perception of institutional order (Djelic \& Quack, 2003, pp. 15-34). It is understood as a consequence of constant negotiations (a strategic game) between entities that strive to achieve their own interests. This process is based primarily on the coordinated actions of a human being who is subject to institutional determinism (Crouch \& Streeck, 1997). It should be emphasized that such a man works in conditions of limited rationality (Rabin, 2013, pp. 528-543). Human activity understood in this way becomes the main determinant for socio-economic growth. This is characteristic of the NIE trend, whose approach to socio-economic phenomena makes the institutional framework a fundamental determinant of economic results (Moesen et al., 2000), It turns out that the institutional determinism of socio-economic phenomena is now becoming a very holistic determinism of economic growth (Delibasic, 2016, pp. 147-159). That is why, in the institutional sense, the planning function is becoming an essential element of managing an organization in the economy in the context of broadly understood institutional determinism (Lai, 2016). The new institutional economics, which emphasizes the pluralistic approach to the economy, is becoming a trend that enables analyzing the institutional aspects of economic growth (Moulaert, 2005). Today, the need to analyze those factors that affect the economic situation is emphasized. Understanding their characteristics, mechanisms of change and understanding their impact on socio-economic phenomena is nowadays necessary for optimal building of business strategies and creating economic policy (Molle, 2003).

The multi-faceted research of neo-institutional economists is evident primarily in the structure of its main theories. There is a debate on the existence of the golden triangle of new institutional economics, which consists of: 1) property and decision rights, 2) contracts, which are mostly incomplete, and 3) transactions carried out in the economy (Ménard, 2018 p. 4). The latter, in a significant way, are associated with transaction costs, which are currently being analyzed in the context of economic and political transactions. Each of them can 
be a source of distortions that generate transaction costs (Stigler, 1971). The wide spectrum of analyzed institutions means that we deal with interactions between them. This means that today we are talking about the so-called general institutional framework. They include macro-institutions (general rules establishing rights and modalities of their allocation), meso-institutions (specific rules delineating the domain of possible transactions and their enforcement) and micro-institutions (organizational arrangements) (Ménard, 2018, pp. 7-9)

Institutions affect socio-economic phenomena also through supervision processes in the economy. This may apply to the financial supervision system, which is becoming the institution that determines the proper functioning of economic entities, here in the context of financial market rules (Masciandaro \& Quintyn, 2015). There are many broad spectrums of impact and sources of institutional determinism in modern economies, e.g., the previously mentioned friction in the economy (Lewis, 1997). Nowadays, the development of the institutional trend has made us talk about institutions. They are becoming the foundation of the multi-faceted economic mechanism today. Regardless of the geographical location of the national economy, institutions are becoming the main subject of consideration in the field of economic policy aimed at optimizing the socio-economic situation in the country (Francois \& Manchin, 2013). It is also worth emphasizing that claims about the quality of institutions are becoming more and more common. It is the most important factor affecting transactions carried out in modern economies. In this context, they - institutions - become the main stimulus of national income (Subramanian et al., 2002). It is also important that the institutions are not permanent entities. The institutions themselves change over time. This is due to many factors (Davis \& North, 2008). In this context, we speak of collapsed, existing or newly created institutions (Staniek, 2012, p. 110). It turns out, therefore, that the quality of institutions is influenced - and this is not a mental mistake - by the impact of various institutional factors. This quality depends on many aspects and remains in real dependence on the level of economic development of a given country (Abdih et al., 2012, p. 657-665). Institutional changes which have been implemented related not only to their "content", but also their quality, which is not without significance for the way the contracting person works. Mentioned earlier 
were the so-called the golden triangle of new institutional economics. In the context of these considerations, however, it is worth highlighting the transactions that are carried out in the economy. It is often taken for granted that private economic transactions, including international ones, can now be carried out easily and at low cost. This would be the result of the globalization. However, this is not obvious. The possibility of executing transactions in the economy depends on the impact of many institutions, including those of international significance. The way of coordinating their implementation in the modern economy is also very important (Medema, 1996; Williamson, 1994). The transaction, seen as a contractual exchange, emphasizes the aspect of ownership (transfer of property rights). As a result, the contract becomes a tool for settling all potential differences between partners, resulting from suboptimal implementation of the contract provisions (Ostrom, 2003). Along with the increase in the complexity of socio-economic reality, on the one hand, and the increase in the number of transactions, also of an international nature, on the other, there has been a need for better and more specialized institutions (Molle, 2003, p. 2), which are to ensure that the transaction will be optimally effective (Araujo et al., 2016).

The institutional structure is nowadays becoming one of the most important issues conditioning economic development, both in the context of economic policy and in the context of organization management (Coase, 2008). Often, the institutional structure becomes a key element in creating a product or service by emphasizing socio-economic producer-consumer relations (Araujo \& Spring, 2006). Also in the context of economic policy, there are increasingly voices that necessitate thinking about the institutional premises of successful capitalism (Minsky, 1996). In this context, it seems reasonable to mention the concept of institutional matrix, which was created on the basis of comparative institutional analyses. The methodology used is based on a holistic approach to socio-economic phenomena. The institutional social structure remains the main subject of research. A comparative method of analysis was used. In addition, a universal "neutral language" was developed to describe the social systems studied (Kirdina, 2014, p. 444-446). This concept presents the institutional structure from three perspectives: economic, political, and ideological projections. Each of these aspects is a specific set of underlying institutions that are important determinants 
of transactions carried out in capitalist economies (Kirdina, 2003). This perception of the institutional structure has become the basis for building a catalogue of diagnostic variables used in the analysis according to the Technique for Order of Preference by Similarity to Ideal Solution (TOPSIS).

\section{METHODS AND MATERIALS}

One of the goals of this article is to present the institutional factors affecting the socio-economic development of the Polish economy. However, it is worth asking a supplementary question of what indicators inform us about economic development. It is important to understand the driving forces behind economic development and update and revise our comprehension of the socio-economic driving factors. It is also important to properly diagnose the current level of development from the perspective of the latest changes (Szirmai, 2015, pp. 73-79). Today, the assessment of economic growth based on the economic GDP indicator is being abandoned. New approaches that accentuate other perspectives of multifaceted socio-economic reality are emerging (Milenkovic et al., 2014). For the purposes of this article, indicators that are part of the contemporary trend towards assessing the level of socio-economic development have been analyzed with the aim of showing the development of the Polish economy in the last two decades.

Nine indicators showing the socio-economic dynamics of the Polish economy were selected. The author wanted to depict the change of individual indicators in the maximum possible time span. However, due tu some restrictions on the availability of data, some indicators do not occur in the maximum time range from 1995 to 2018. The following indicators have been selected:

- Gross national income per capita,

- Service sector's share in GDP,

- Infant mortality (per 1000 births),

- Average life expectancy,

- Energy consumption in $\mathrm{kWh}$ per capita,

- Total population per 1 doctor,

- Individuals internet use - percentage of individuals,

- Gini coefficient of equivalized disposable income. 
In order to compare the presented data and their compilation as a common figure, they were standardized according to the principle presented in the formula:

$$
V_{S}=\frac{v-\alpha}{\beta}
$$

where: $v$ - the value of the observed variable, $\alpha$ - the average value of observed variables, $\beta$ - standard deviation.

In this way, normalized values $\left(V_{S}\right)$ were calculated for all the indicators analyzed. They are presented in the next part of the article. The values marked with a dashed line mean that their expected value should decrease as the level of socio-economic development increases. Other values should increase along with the country's economic growth. Additionally, the Human Development Index has been presented.

Values for the Polish economy are presented in the next chapter. The time range of the presented data results from the availability of data (1990-2018), which are presented under the United Nations Development Program (UNDP).

One of the more popular methods used in the analyses of economic development is the taxonomic measure of development by Zdzisław Hellwig. It involves making the analyzed phenomenon more specific by creating a set of economic aspects. They are described by a array of diagnostic variables (Nermend, 2007). In this way, an optimally holistic description of the socio-economic phenomena analyzed is obtained. Then, a synthetic variable is designated, which has been called the taxonomic measure of development (TMD). Thanks to the adopted assumptions, TMD takes into account a wide spectrum of the adopted determinants shaping the analyzed phenomenon. The procedure for determining the synthetic variable is based on a comparison of subsequent objects with the reference object (Bielak \& Kowerski, 2018).

An equally popular tool that is an extension of the Hellwig method is the Technique for Order Preference by Similarity to Ideal Solution (TOPSIS). The main and most important advantage of this method is the way in which the taxonomic measures of development are determined. It consists in determining the relative distances of the studied variables to their reference and anti-reference. 
The method is used mainly for a multifaceted analysis of economic phenomena in which it is possible to distinguish numerous economic aspects (Ozturk \& Batuk, 2011), and because of this, the author decided to use the TOPSIS method in this article. Hence, a detailed analysis, which consisted of two stages, was carried out for this purpose. In the first stage, economic phenomena were analyzed using diagnostic variables. This enabled the author to assess the individual aspects and select the economies in which they have been adopted. In the second stage, a detailed analysis of the diagnostic variables was carried out. The result of this stage was the determination of taxonomic measures of development for individual countries in the analyzed period of time.

The detailed procedure for calculating the TMD indicator, using the TOPSIS method, consisted of several main steps:

1. Adoption of specific economic phenomena $\left(O_{i}\right.$, where $\left.i \in\{1 \ldots n\}\right)$ for each of the economic aspects $\left(A_{k}\right.$, where $\left.k \in\{1 \ldots n\}\right)$. In conducted analyses, these aspects mean geographical aspects (economies of selected countries). This will allow for the TMD to be calculated for a particular economy as the Euclidean distance from the reference and anti-reference values for individual economic phenomena.

2. Determining for each geographical aspect a set of diagnostic variables $\left(X_{i j}^{k}\right.$, where $\left.j \in\{1 \ldots m\}\right)$, which detail individual economic phenomena and determine their weights.

3. Determining the nature of diagnostic variables due to their impact on the economic phenomenon (stimulant/destimulant).

4. Determining the normalized matrix of diagnostic variables according to the formula for each geographical aspect:

$$
\bar{X}_{i j}^{k}=\frac{X_{i j}^{k}}{\sqrt{\sum_{j=1}^{m} X_{k i j}^{2}}}
$$

Specification of reference $\left(W_{k, j}^{P}\right)$ and anti-reference $\left(W_{k, j}^{N}\right)$ values for individual diagnostic variables.

$$
\begin{aligned}
& W_{k, j}^{P}=\max \left(X_{i j}^{k}\right) \\
& W_{k, j}^{N}=\min \left(X_{i j}^{k}\right)
\end{aligned}
$$


5. Determining the distance of Euclidean diagnostic variables from reference and anti-reference values for each geographical aspect. Due to the fact that the analyses will cover a long period of time, these values are calculated for 2018. This means that TMD in individual periods (year) is calculated on the basis of Euclidean distances to the reference and anti-reference values from 2018.

$$
d_{k, i t}^{P}=\left[\sum_{j=1}^{m}\left(\bar{X}_{i j}^{k}-W_{k, j}^{P}\right)^{2}\right]^{0,5} \text { and } d_{k, i t}^{P}=\left[\sum_{j=1}^{m}\left(\bar{X}_{i j}^{k}-W_{k, j}^{N}\right)^{2}\right]^{0,5}
$$

6. The taxonomic measure of development for each geographical aspect, within the limits of a particular economic phenomenon, was calculated from the formula:

$$
T M D_{i t}^{k}=\frac{d_{k, i t}^{N}}{d_{k, i t}^{P}-d_{k, i t}^{N}}
$$

7. Steps from 3 to 7 were repeated for each economic phenomenon ().

8. The weight for each of the analyzed economic phenomena was determined, and on this basis the taxonomic measure of development was calculated for each geographical aspect in time.

$$
T M D_{t}=\sum_{k=1}^{n} w_{k} T M R_{i t}^{k}
$$

9. On this basis, the ranking for each geographical aspect was determined. The above activities were repeated for all the analyzed years (from 2008 to 2018). The analysis period was limited by the availability of all data for individual diagnostic variables. The obtained taxonomic measure of development results from the TOPSIS analysis range from 0 to 1 . TMD values allow for the analysis of the importance of individual determinants for the economic growth of individual economies. The use of many criteria and the use of weighted Euclidean distances allows us to draw objective conclusions (Deng et al., 2000). High values of the taxonomic indicator speak of a high level of development of a particular national economy from the perspective of all economic phenomena. 


\section{DISCUSSION AND RESULTS. SOCIO-ECONOMIC DEVELOPMENT OF POLAND}

First of all, the author will present the most important indicators showing Poland's socio-economic development. For this purpose, a set of data from various sources was used. They are presented in Table 1. Missing values of individual indicators results from the lack of data for individual years, unfortunately, such limitations are unavoidable. However, the analysis of the changes in individual quantities from 2005 may show a clear picture of the development of the Polish economy. The data presented here shows a very clear increase in gross national income. The average yearly increase of this amount has exceeded $8.2 \%$ since 1995 . The situation is different for the indicator of the share of the services sector in total GDP. The average annual increase in the whole period was only $0.55 \%$. In the period from 1995 to 2002 , this increase was at the level of $2.1 \%$. In subsequent years, this indicator remained almost constant. In the years 2002-2018, the average annual growth reached the value of $-0.1 \%$. This situation should be considered negative for the growth rate of the Polish economy, which is confirmed by numerous economic literature (Mansell, 1985).

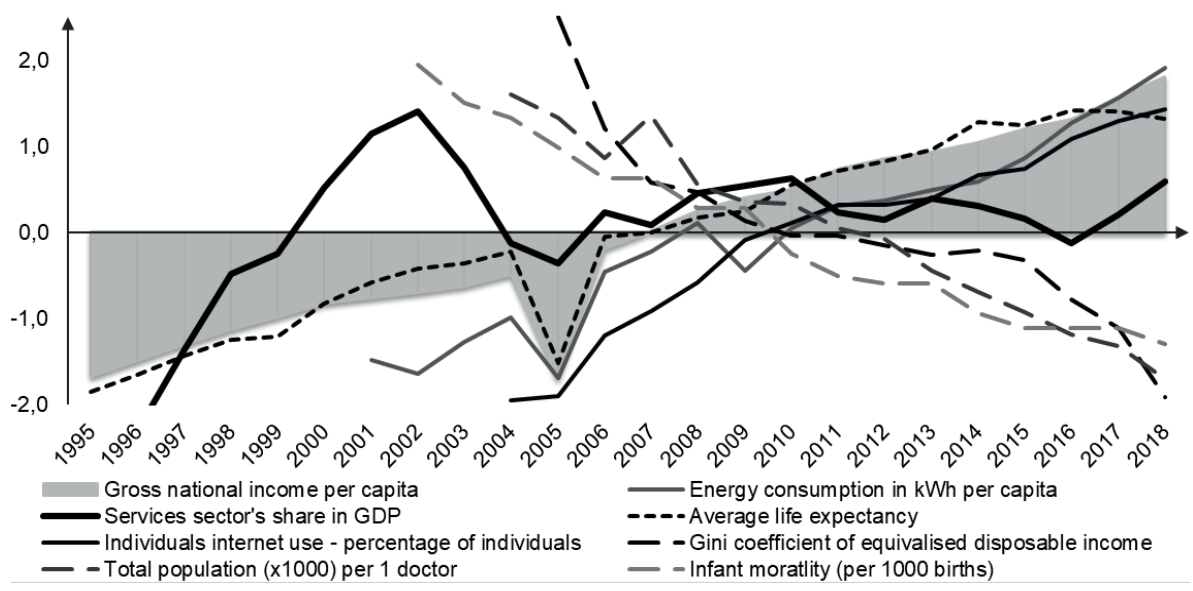

Figure 1. Human development index (HDI) for Poland Source: own work based on UN's UNDP.

A positive picture emerges from the analysis of the indicator of the average life of Poles. In the evaluated period, the average life 


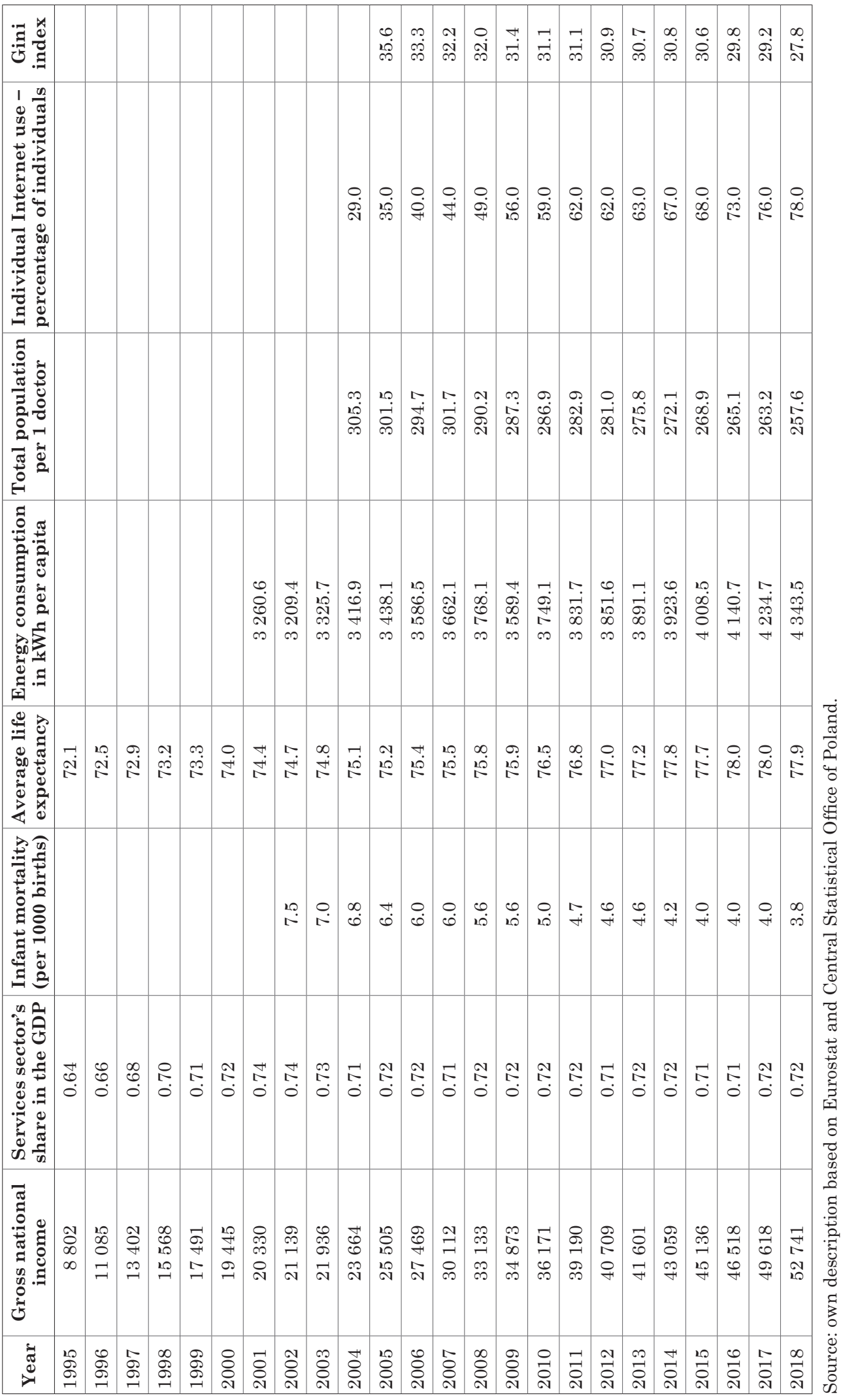


expectancy increased by 5.7 years for the general population. The electricity consumption indicator shows a similar relationship for socio-economic development. In the period from 2001 to 2018, an average annual increase in electricity consumption of $1.73 \%$ was recorded. Due to the growing importance of new technologies for socio-economic development, the Internet accessibility index is used. The author used the individual Internet use - percentage of individual indicator. In the period from 2004 to 2018, the average annual increase of the indicator reached the level of $7.5 \%$. It is worth noting that the growth rate of this size was high in 2004-2011 and reached the level of $11.6 \%$. In the following years, the growth of this indicator slowed down to $3.4 \%$. Table 2 shows the indicators of infant mortality (per 1000 births), total population per 1 doctor and Gini coefficient of equalized disposable income (Gini index). Their common feature is that their decline indicates a positive increase in the socio-economic development of the country. This situation can be seen in the Polish economy. The first indicator decreased on average by $4.10 \%$ on average, the second by $1.2 \%$ and the last indicator by $1.87 \%$.

Table 2. Economic aspect and perspectives

\begin{tabular}{|l|l|c|}
\hline Economic perspective & \multicolumn{1}{|c|}{ Political perspective } & Social perspective \\
\hline economy and finance & economic freedom & population and social conditions \\
\hline industry & governance quality & - \\
\hline science and technology & environment & - \\
\hline \multicolumn{1}{|c|}{-} & infrastructure & - \\
\hline
\end{tabular}

Source: own work.

The data presented in Table 1 have been standardized, which is illustrated in Figure 1. There are three types of changes in the indicators analyzed quite clearly. The first relates to gross national income per capita, average life expectancy, energy consumption in $\mathrm{kWh}$ per capita and individuals Internet use - percentage of individuals. Their common feature is that their growth is a symptom of socio-economic growth. The confirmation of this is the analysis of standardized indicators. The Service sector's share in GDP should be similar. Here, however, a different situation can be seen. This means that we are talking about the second type of changes in the analyzed indicator. It is quite clear that the dynamics 
of changes in the share of the services sector in GDP differs from the upward trend. On this basis, one might dare to say that this indicator reveals a sub-optimal situation in the economy that prevents effective socio-economic growth. The third type of changes in the analyzed indicators was illustrated by wide-dashed lines. This group includes those indicators that are inversely dependent on socio-economic growth. This means that the decrease in these values in the analyzed period stimulates Poland's economic growth.

Confirmation of the conclusions drawn from the data above, may be seen in a change in the value of Human Development Index (HDI). Data for Poland for the period from 1990 to 2018 are presented in Figure 2. On this basis, it can be said that the Polish economy developed slightly faster in the period from 1993 to 2002, when the HDI index increased by $1.13 \%$ on average per year. In subsequent years, the growth rate of this indicator slowed down. In the period from 2003 to 2018, the HDI index increased by $0.55 \%$. On the basis of the indicators presented here, it can be unequivocally stated that the Polish economy in the analyzed period recorded a clear socio-economic growth.

The results of the TOPSIS analysis, which was aimed at revealing the institutional factors of socio-economic development of Poland against the background of selected European economies, should be

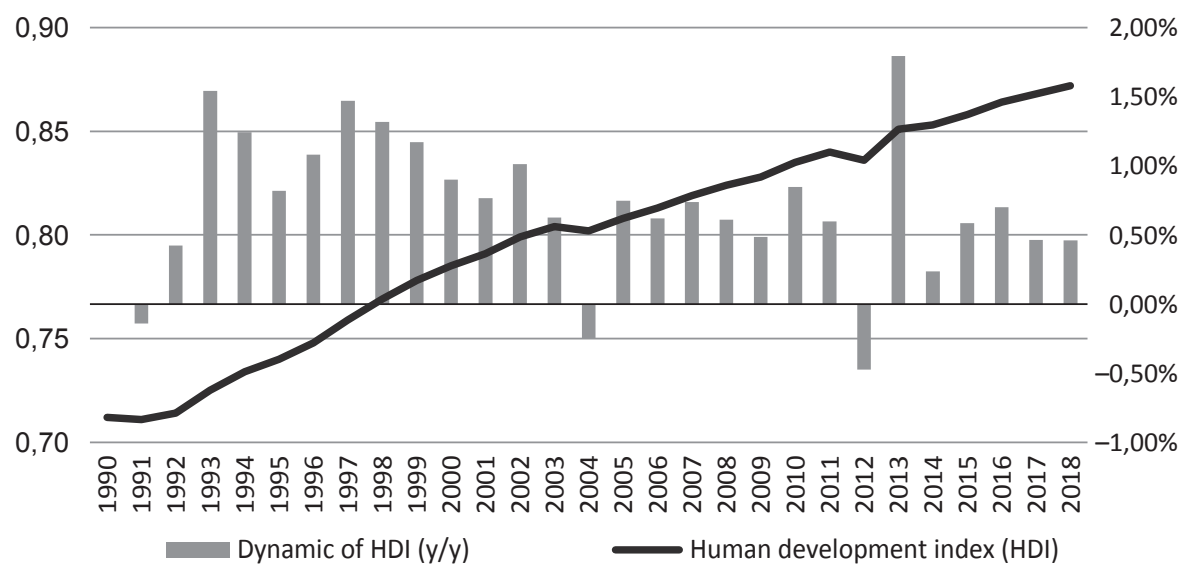

Figure 2. Human development index (HDI) for Poland

Source: own work based on UN's UNDP. 
presented here. The collected statistical data allowed for a detailed analysis in the period from 2008 to 2018 . Based on the assumption of Kirdina's institutional matrix (Kirdina, 2001), the author attempted to define economic aspects and to select diagnostic variables that would reflect the socio-economic situation in selected 10 national economies. In this way, eight economic phenomena were obtained, which were inscribed in individual perspectives of the institutional matrix (see Table 2). A detailed list of diagnostic variables assigned to individual economic phenomena is presented in Appendix A. All presented values were referred to individual economic aspects, for which the author adopted individual economies of the analyzed countries. In addition to Poland, the author analyzed the economies of Bulgaria, Czech Republic, France, Germany, Hungary, Lithuania, Latvia, Slovakia, and Spain.

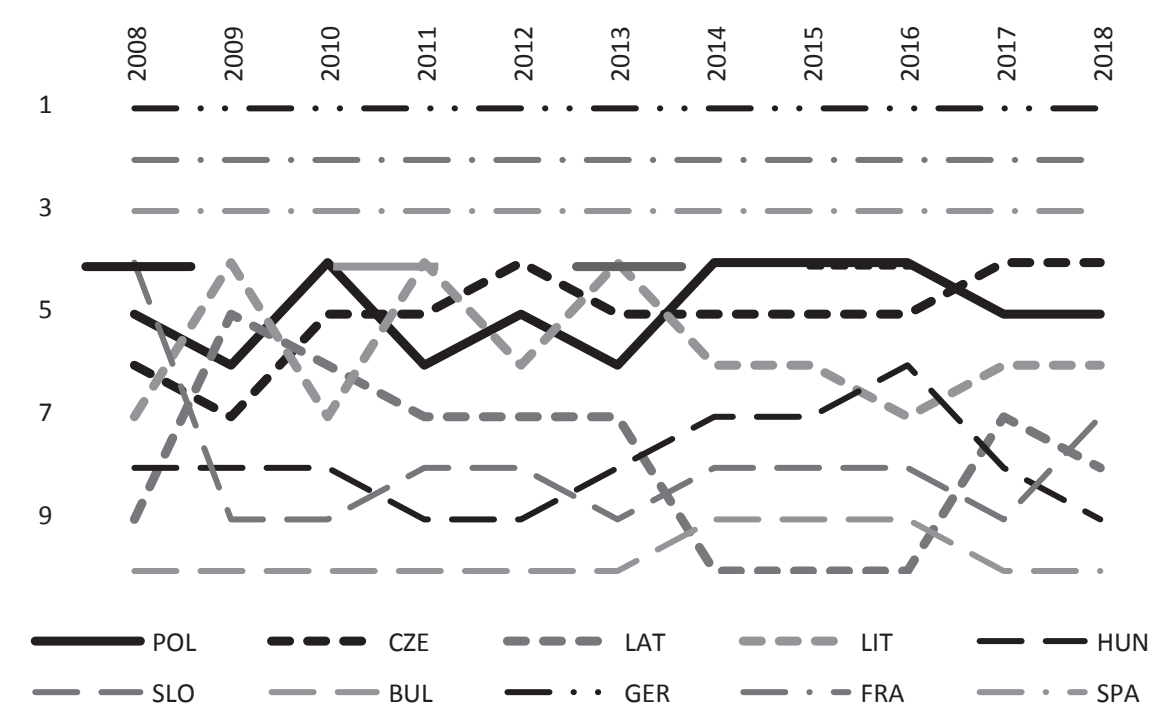

Figure 3. Taxonomic measure of development - country ranking Source: own work.

The analysis of Poland's socio-economic development was carried out according to the TOPSIS method. To this end, all 89 diagnostic variables, aggregated into 8 economic phenomena, were analyzed for each national economy. In this way, taxonomic measures of development were calculated for each of the analyzed countries in the period from 2008 to 2018. The final results are presented in Table 3. 
Table 3. Taxonomic measure of development

\begin{tabular}{|l|l|l|l|l|l|l|l|l|l|l|l|}
\hline Country & $\mathbf{2 0 0 8}$ & $\mathbf{2 0 0 9}$ & $\mathbf{2 0 1 0}$ & $\mathbf{2 0 1 1}$ & $\mathbf{2 0 1 2}$ & $\mathbf{2 0 1 3}$ & $\mathbf{2 0 1 4}$ & $\mathbf{2 0 1 5}$ & $\mathbf{2 0 1 6}$ & $\mathbf{2 0 1 7}$ & $\mathbf{2 0 1 8}$ \\
\hline Bulgaria & 0.364 & 0.329 & 0.335 & 0.349 & 0.342 & 0.333 & 0.360 & 0.364 & 0.372 & 0.341 & 0.365 \\
\hline $\begin{array}{l}\text { Czech } \\
\text { Republic }\end{array}$ & 0.414 & 0.395 & 0.406 & 0.406 & 0.407 & 0.410 & 0.438 & 0.422 & 0.439 & 0.447 & 0.444 \\
\hline France & 0.581 & 0.546 & 0.568 & 0.559 & 0.546 & 0.553 & 0.538 & 0.560 & 0.541 & 0.556 & 0.549 \\
\hline Germany & 0.642 & 0.664 & 0.707 & 0.705 & 0.683 & 0.692 & 0.689 & 0.691 & 0.698 & 0.704 & 0.697 \\
\hline Hungary & 0.385 & 0.359 & 0.387 & 0.359 & 0.364 & 0.370 & 0.416 & 0.396 & 0.415 & 0.391 & 0.366 \\
\hline Latvia & 0.377 & 0.400 & 0.400 & 0.373 & 0.381 & 0.394 & 0.343 & 0.359 & 0.362 & 0.392 & 0.380 \\
\hline Lithuania & 0.390 & 0.411 & 0.400 & 0.408 & 0.390 & 0.419 & 0.429 & 0.407 & 0.405 & 0.409 & 0.403 \\
\hline Poland & 0.422 & 0.396 & 0.423 & 0.403 & 0.401 & 0.405 & 0.442 & 0.442 & 0.442 & 0.444 & 0.431 \\
\hline Slovakia & 0.430 & 0.353 & 0.384 & 0.372 & 0.376 & 0.369 & 0.368 & 0.381 & 0.373 & 0.369 & 0.385 \\
\hline Spain & 0.527 & 0.484 & 0.501 & 0.486 & 0.483 & 0.490 & 0.506 & 0.492 & 0.504 & 0.466 & 0.469 \\
\hline AVG & 0.453 & 0.434 & 0.451 & 0.442 & 0.437 & 0.444 & 0.453 & 0.451 & 0.455 & 0.452 & 0.449 \\
\hline
\end{tabular}

Source: own work.

On this basis, rankings for individual countries were determined. They are presented in Figure 3.

It is clear that Germany, France, and Spain are the leaders among the analyzed countries. The Polish economy is "fighting" for a place in the ranking with the Czech Republic and Lithuania. Other countries rank 7 to 10. It is also worth presenting the TMD indicator for Poland, Lithuania and the Czech Republic in relation to its average value for the 10 countries analyzed (see Figure 4). It can be seen that in the years from 2008 to 2013 TMD indices for these countries were quite different from the average value. 2014 was a time of positive correction. Since then, the Polish and Czech economy has been experiencing very similar socio-economic growth. 


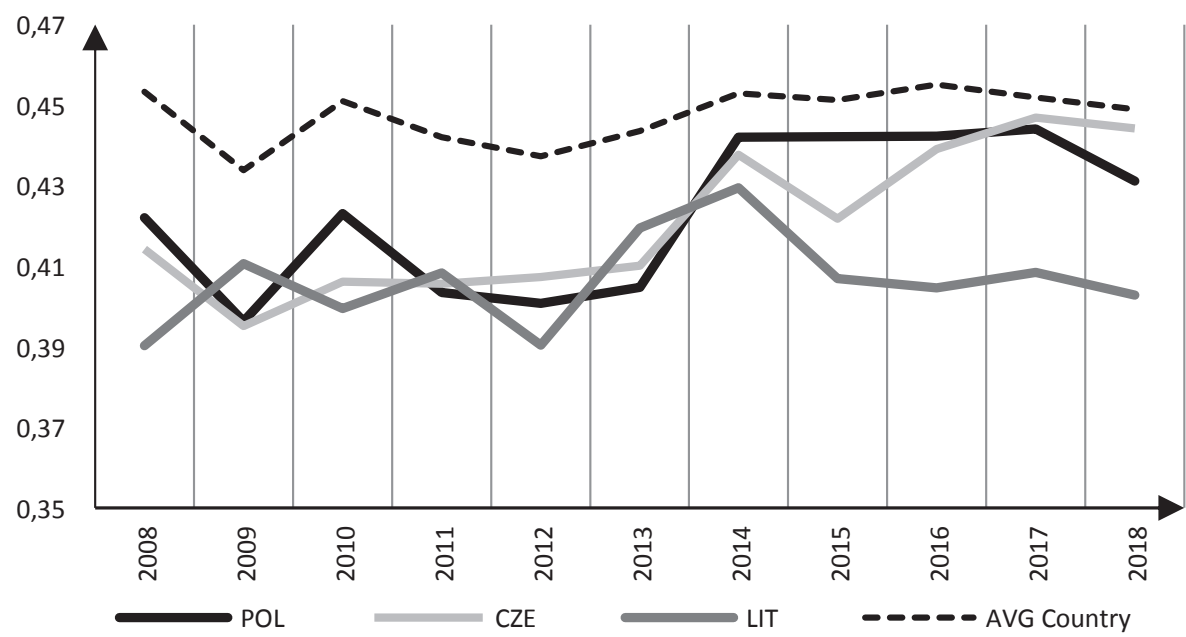

Figure 4. Taxonomic measure of development - average value Source: own work.

It is also worth presenting taxonomic measures of development calculated for individual economic phenomena. These values for the Polish economy are illustrated in Figure 5.

This analysis shows how individual socio-economic phenomena affect the final value of the TMD indicator. The author has adopted the following weights for individual economic phenomena.

- Economy and finance -0.25

- Population and social conditions - 0.15

- Industry - 0.20

- Environment - 0.10

- Science and technology -0.10

- Economic Freedom - 0.10

- Governance Quality - 0.05

- Infrastructure - 0.05

Comparing the quantities describing economic phenomena to the general taxonomic measure of socio-economic development, several conclusions can be drawn. It can be seen that in the analyzed period, some of the economic phenomena achieved higher values than the TMD indicator for Poland, out of which the TMD indicator of economic freedom stands out. Practically for the entire length of the analyzed period, three TMD indicators achieve a value lower 


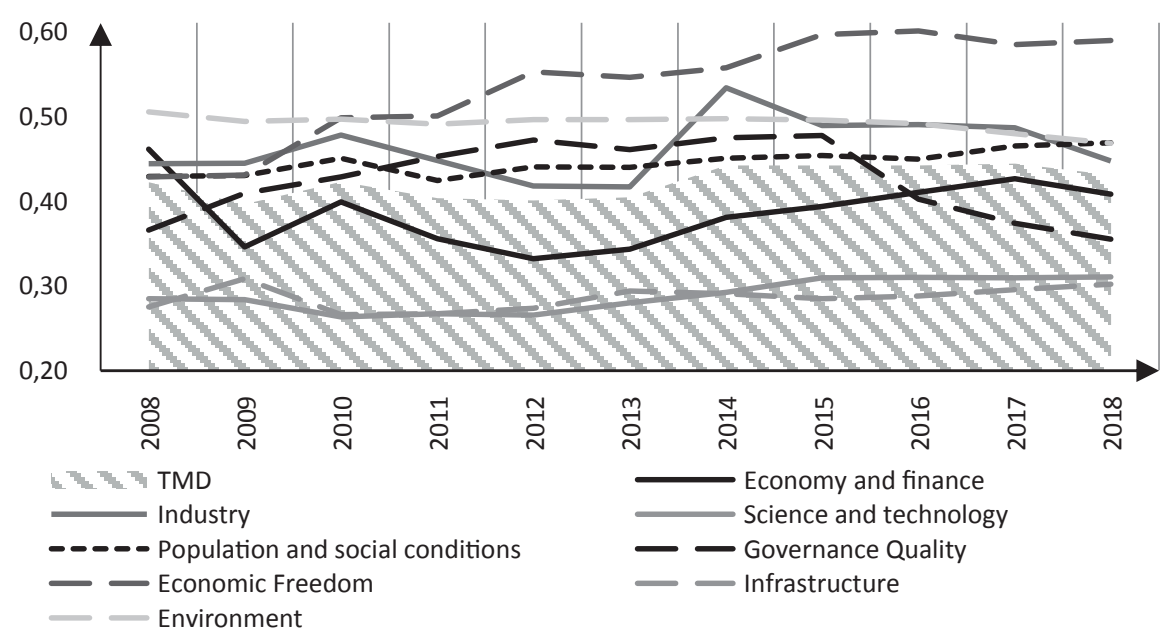

Figure 5. Taxonomic measure of development for economic phenomena in Poland

Source: own work.

than the taxonomic measure of development for Poland. These are the economic phenomena: economics and finance, science, and technology and infrastructure. This will mean that diagnostic variables describing these economic phenomena slow down the socio-economic development of Poland. Also noteworthy is the TMD indicator for the economic phenomenon referred to as Governance quality. It can be seen that since 2016, this indicator has clearly been depreciating. This fact has certainly had a negative impact on the socio-economic development of the Polish economy. However, precise conclusions from this fact should be drawn in the context of the analysis of the methodology used (Brandt et al., 2019).

At this point, it seems reasonable to include the results of taxonomic indicators of socio-economic development in the institutional matrix. For this purpose, average values of TMD indices for individual economic phenomena were calculated, which were grouped according to institutional perspectives (see: Table 2). In this way, we obtain an institutional picture of the determinism of socio-economic development for the 10 countries analyzed. Figure 6 shows the results for Poland in 2018. These figures were compared to the results of Czechia, Lithuania, and Germany. The analysis of this graph is an opportunity for drawing some interesting conclusions. It is clear that the sphere of institutional determinism of the Polish economy is 


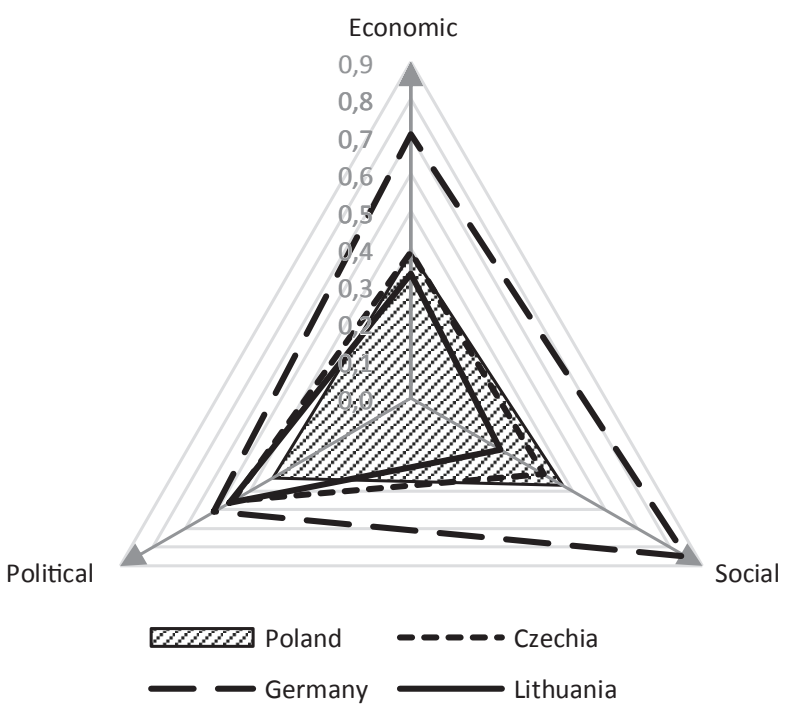

Figure 6. Institutional matrix based on TMD, year 2018

Source: own work.

definitely weaker than the German economy. Particularly large differences occur in the social and economic perspective. Comparing the Polish institutional sphere to the Czech one, it can be seen that the latter has more powerful institutions that fit into the political perspective. Such an illustration of the results of the taxonomic measure analysis of socio-economic development can have two meanings. First of all, these results make it possible to diagnose the strengths and weaknesses of the national economy from the perspective of individual economic phenomena that fall under individual institutional perspectives. On the other hand, a comparative analysis makes it possible to create the basis for building appropriate economic policies that will be aimed at strengthening those institutions (diagnostic variable values) that deviate from average values or from benchmarks of national economies.

It seems obvious that drawing such conclusions requires further detailed analysis of individual diagnostic variables and economic phenomena within the national economy. Due to the editorial restrictions of the article, the author can present only a general outline. A thorough analysis of taxonomic measures of development, calculated for individual economic phenomena, in the analyzed period may prove particularly valuable. Detailed data for the analyzed 


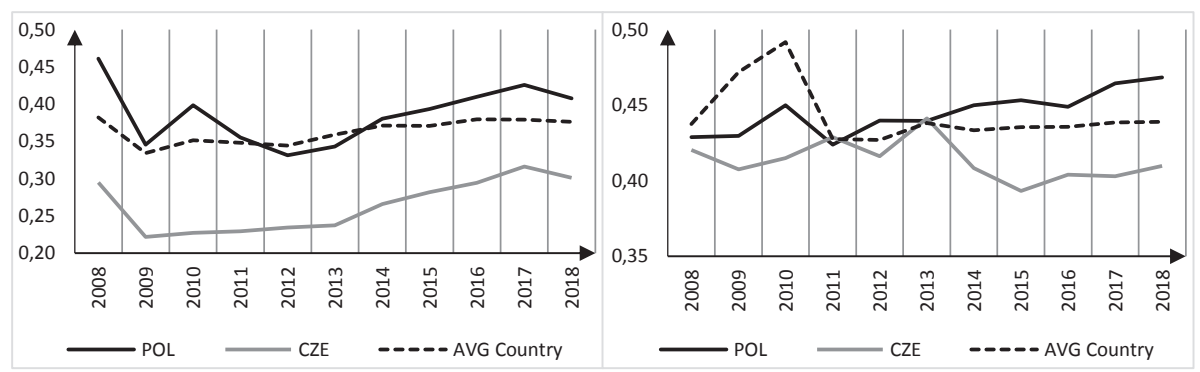

Figure 7a. TMD - Economic and Figure 7b. TMD - Population and finance social conditions

Source: own work.

Source: own work.

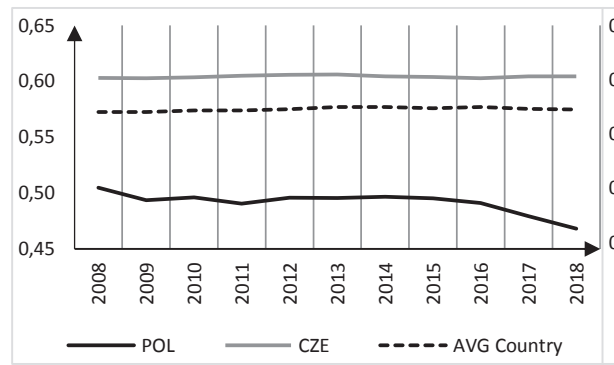

Figure 7c. TMD - Environment

Source: own work.

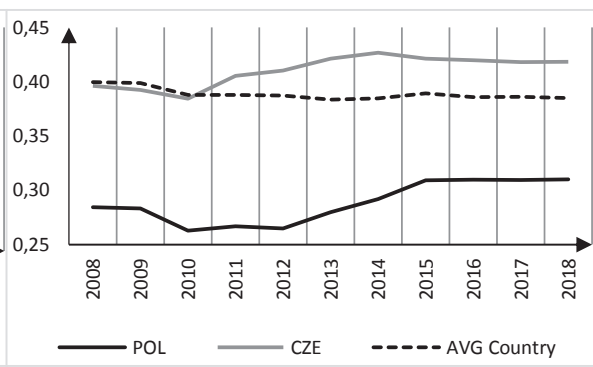

Figure 7d. TMD - Science and technology

Source: own work.

countries are presented in Appendix B. This will suffice to illustrate selected economic phenomena in the following figures (see: Figure $7 \mathrm{a}-\mathrm{d})$. It can be seen that the taxonomic measures of the development of the Polish economy, for the first two economic phenomena, have exceeded their average level for the 10 analyzed countries since 2013. In turn, the TMD inicator for the environment, science and technology is well below average.

At this stage, the issue of how individual determinants (diagnostic variables) affect the size of the taxonomic measure of socio-economic development within the limits of one economic phenomenon can be reflected upon. It should be borne in mind, as it has been mentioned in the previous part of the article, that individual diagnostic variables may be stimulants or, quite contrary, have a destimulating effect. In addition, each of the determinants was shaped by the weight as part of the economic phenomenon. At this point, the baseline elements of the analysis will be estimated standard and anti-standard values. In this context, a detailed analysis of 


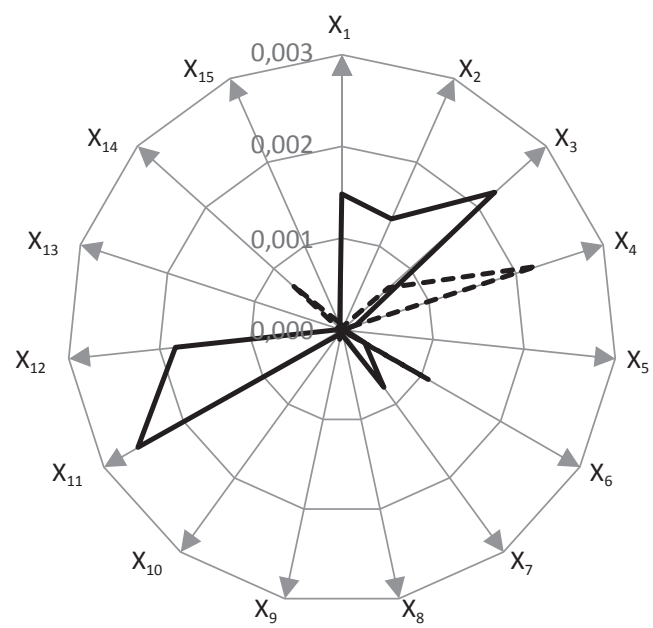

Distances to pattern

Distances to the anti-pattern

Figure 8. Euclidean distances from the pattern and anti-pattern (stimulant and destimulant) - Poland, year 2018

Source: own work.

individual determinants will consist in establishing the Euclidean distances of the diagnosed factors to their patterns and anti-patterns. Figure 8 presents an example of such an analysis, namely, the diagnostic variables (from $\mathrm{X}_{1.1}$ to $\mathrm{X}_{1.15}$ ) for the economic phenomenon of economics and finance (see Appendix A), which was diagnosed for the Polish economy in 2018. The optimal situation will be characterized by a greater distance from the anti-predictor and a smaller distance from the standard for individual diagnostic variables.

Figure 9 shows the average value of socio-economic development indicators and the taxonomic indicator of the development of the Polish economy.

An analysis of these data reveals two stages of development. The first, which takes us up to 2006, is a time of very high growth dynamics. From 2002 to 2005 a strong negative correction of this trend can be seen. The second stage begins a year after Poland's accession to the European Economic Area and two years after accession to the European Union. From 2006 onwards, three-year cycles of changes in the average size of socio-economic development indicators in the Polish economy begin to appear. The ASEDI (average size of all socio-economic development indicators) chart can be compared to a TMD chart. It turns out that from 2008 to 2018, a quite 


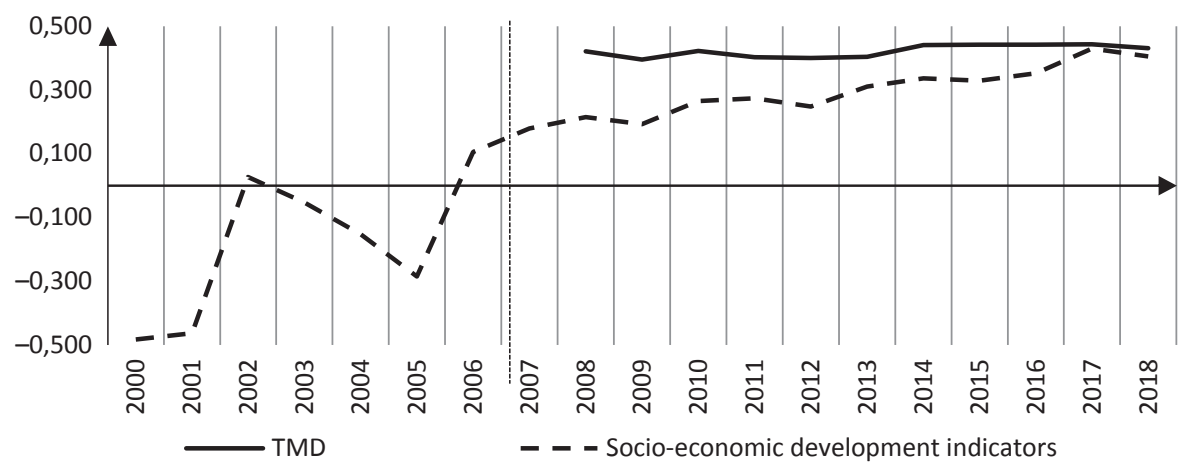

Figure 9. Comparison of indicators of the Polish economy

Source: own work.

strong correlation between these values develops. The Pearson index is 0.78 . On this basis, it can be concluded that the socio-economic growth of Polish economic activity is strongly dependent on the TMD indicator. This indicator was calculated on the basis of 89 diagnostic variables, which were grouped into 8 economic phenomena. Each of them was referred to the appropriate institutional perspective. Analyses revealed the significant impact of determinants (diagnostic variables) on the final level and quality of socio-economic development of Poland in comparison with 10 selected European countries.

\section{CONCLUSIONS}

The analyses presented above aimed at determining the taxonomic measure of development for the Polish economy and have become the basis for determining the level of socio-economic development. A comparative analysis of TMD indicators for Poland in relation to selected European countries has made it possible to present the ranking. It turned out that in 2018 Polish socio-economic development came in the fifth place among the 10 analyzed countries. The analysis of the three countries (Germany, France and Spain) representing economies which historically had the opportunity to enter the path of development earlier, places Poland at the forefront. The conducted analyses, in the period from 2000 to 2018, allows to draw a conclusion that the socio-economic development of the Polish economy since 1995 is very clear. The stabilization of this development has 
been visible since 2006, which is visible in the socio-economic development indicators presented earlier (see: Table 1). The usage of standardized data allowed for a comparative analysis and calculation of the ASEDI. It can, therefore, be said that the adopted diagnostic variables are a set of institutional factors that affect the dynamics of the socio-economic development of the Polish economy.

The conclusions resulting from this analysis may constitute a basis for further research. The author is aware that the socio-economic development of the Polish economy is determined by a large number of different institutions. By no means do the 89 variables selected here form a comprehensive catalogue of the institutional determinants important for economic development. The institutional approach to this issue shows the importance of institutional determinism. It can be assumed that economic research on socio-economic development should refer to the institutional matrix. The ASEDI cycles are also quite surprising.

It can be stated that Polish economic policy should be built on the basis of holistic socio-economic determinism. The strategy for socio-economic development should go beyond the calendar of parliamentary elections. Although the political perspective is one of the three base institutions, it is not the only one. The analysis of the presented research suggests a possible scenario that further dynamic socio-economic development of Poland should be based on the development of social and economic aspects.

\section{REFERENCES}

Abdih, Y., Ralph, C., Jihad, D. \& Montiel, P. (2012). Remittances and Institutions: Are Remittances a Curse? World Development, 40(4), 657-666.

Araujo, L., Mion, G. \& Ornelas, E. 2016. Institutions and Export Dynamics. Journal of International Economics, 98, 2-20.

Araujo, L. \& Spring, M. (2006). Services, Products, and the Institutional Structure of Production. Industrial Marketing Management, 35(7), 797-805.

Bielak, J. \& Kowerski, M. (2018). Dynamics of Economic Development Measure. Fiftieth Anniversary of Publication of the Article by Prof. Zdzisław Hellwig. Barometr Regionalny. Analizy i Prognozy, 16(4), 153-165.

Brandt, C., Linzer, I., O'Toole, S. \& Puddington, A. (2019). Freedom in the World 2019. Washington/New York: Freedom House. 
Coase, R.H. (1937). The Nature of the Firm. Economica, 4(16), 386-405.

Coase, R.H. (1984). The New Institutional Economics. Journal of Institutional and Theoretical Economics, 140, 229-231.

Coase, R.H. (1998). The New Institutional Economics. American Economic Review, 88(2), 72-74.

Coase, R.H. (2008). The Institutional Structure of Production. In: C. Ménard \& M.M. Shirley (Eds.). Handbook of New Institutional Economics. Heidelberg: Springer-Verlag.

Crouch, C. \& Streeck, W. (1997). Political Economy of Modern Capitalism: Mapping Convergence and Diversity. London: Sage.

Czetwertyński, S. (2019). The Gnoseological Sense of a New Paradigm of the Institutional Economics. Ekonomia i Prawo. Economics and Law, 18(2), 165-181.

Davis, L.E. \& North, D.C. (2008). Institutional Change and American Economic Growth. Cambridge: Cambridge University Press.

Delibasic, M. (2016). Hypothetical Matrix for Institutional Modeling of the Basis for Economic Development in the Countries of Southeast Europe. Montenegrin Journal of Economics, 12(2), 147.

Deng, H., Yeh, C.H. \& Willis, R.J. (2000). Inter-Company Comparison Using Modified TOPSIS with Objective Weights. Computers \& Operations Research, 27(10), 963-973.

Djelic, M.L. \& Quack, S. (2003). Theoretical Building Blocks for a Research Agenda Linking Globalization and Institutions. In: M.L. Djelic \& S. Quack (Eds.). Globalization and Institutions: Redefining the Rules of the Economic Game. Cheltenham: Edward Elgar.

Francois, J. \& Manchin, M. (2013). Institutions, Infrastructure, and Trade. World Development, 46, 165-175.

Hodgson, G.M. (2006). What Are Institutions? Journal of Economic Issues, XL(1), $1-25$.

Kirdina, S. (2003). Institutional Matrices and Institutional Changes. The 5th International Symposium on Evolutionary Economics. Pushchino, 182-195.

Kirdina, S. (2014). Institutional Matrices and Development of Russia: Introduction to X-Y-Theory. Moscow-Saint Petersburg: Nestor-Istoriya.

Kirdina, S. \& Sandstrom, G. (2010). Institutional Matrices Theory as a Framework for Both Western and Non-Western People to Understand the Global Village. Non-Western Challenges to Western Social Theory. Gothenburg: International Sociological Association.

Kleiner, G.B. (2004). Evoljucyja Institutocyonalnych Sistiem. Moskwa: Nauka.

Lai, L.W.C. (2016). Neo-Institutional Economics and Planning Theory. Planning Theory, 4(1), 7-19. 
Lewis, T.G. (1997). The Friction-Free Economy: Marketing Strategies for a Wired World. New York: HarperBusiness.

Mansell, R.L. (1985). The Service Sector and Western Economic Growth. Canadian Public Policy/Analyse de Politiques, 11, 354-360.

Masciandaro, D. \& Quintyn, M. (2015). Institutions Matter: Financial Surepvision Architecture, Central Bank and Path-Dependence, General Trends and the South Eastern European Countries. South-Eastern Europe Journal of Economics, 8(1).

Medema, S.G. (1996). Coase, Costs, and Coordination. Journal of Economic Issues, $30(2), 571-578$.

Ménard, C. (2018). Research Frontiers of New Institutional Economics. RAUSP Management Journal, 53(1), 3-10.

Milenkovic, N., Vukmirovic, J., Bulajic, M. \& Radojicic, Z. (2014). A Multivariate Approach in Measuring Socio-Economic Development of MENA Countries. Economic Modelling, 38, 604-608.

Minsky, H.P. (1996). Uncertainty and the Institutional Structure of Capitalist Economies. Journal of Economic Issues, 30(2), 357-368.

Moesen, W., Puyenbroeck, T.V. \& Cherchye, L. (2000). Trust as Societal Capital: Economic Growth in European Regions. CES-Discussion Paper Series (DPS) 00.01, 1-25.

Molle, W. (2003). Global Economic Institutions. London-New York: Routledge.

Moulaert, F. (2005). Institutional Economics and Planning Theory: A Partnership between Ostriches? Planning Theory, 4(1), 21-32.

Nermend, K. (2007). Taxonomic Vector Measure of Region Development (TWMRR). Polish Journal of Environmental Studies, 16(4A), 195-198.

North, D.C. (2008). Institutions and the Performance of Economies Over Time. In: C. Ménard \& M.M. Shirley, Handbook of New Institutional Economics. Heidelberg: Springer-Verlag.

Obińska-Wajda, E. (2016). The New Institutional Economics-Main Theories. E-Finanse, 12(1), 78-85.

Ogilvie, S. (2014). The Economics of Guilds. Journal of Economic Perspectives, 28(4), 169-192.

Ostrom, E. (2003). How Types of Goods and Property Rights Jointly Affect Collective Action. Journal of Theoretical Politics, 15(3), 239-270.

Ozturk, D. \& Batuk, F. (2011). Technique for Order Preference by Similarity to Ideal Solution (TOPSIS) for Spatial Decision Problems. Proceedings ISPRS.

Rabin, M. (2013). Incorporating Limited Rationality into Economics. Journal of Economic Literature, 51(2), 528-543. 
Staniek, Z. (2012). Równowaga Instytucjonalna i Jej Wymiary. In: S. Rudolf (Ed.), Nowa ekonomia instytucjonalna wobec kryzysu gospodarczego. Kielce: WSEiP.

Stelter, B. (2019). The Management Approach of the New Institutional Economics. Ekonomia i Prawo. Economics and Law, 18(1), 73-81.

Stigler, G.J. (1971). The Theory of Economic Regulation. The Bell Journal of Economics and Management Science, 3-21.

Subramanian, A., Trebbi F. \& Rodrik, D. (2002). Institutions Rule: The Primacy of Institutions over Integration and Geography in Economic Development. Washington, DC: International Monetary Fund.

Szirmai, A. (2015). Socio-Economic Development. Cambridge: Cambridge University Press.

Veblen, T. (2017). The Theory of the Leisure Class. London-New York: Routledge.

Williamson, O.E. (1985). The Economic Institutions of Capitalism: Firms, Markets, Relational Contracting. SSRN Scholarly Paper. ID 1496720. Rochester, NY: Social Science Research Network.

Williamson, O.E. (1994). Comparative Economic Organization. The Analysis of Discrete Structural Alternatives. San Francisco, CA: An International Center for Economic Growth Publication.

Williamson, O.E. (2000). The New Institutional Economics: Taking Stock, Looking Ahead. Journal of Economic Literature, 38, 595-613.

Williamson, O.E. (2002). The Theory of the Firm as Governance Structure: From Choice to Contract. Journal of Economic Perspectives, 16(3), 171-195. 


\title{
OD RYNKU WSCHODZĄCEGO DO ROZWINIĘTEGO - NEOINSTYTUCJONALNE PODEJŚCIE NA PRZYKŁADZIE POLSKI
}

\begin{abstract}
Abstrakt
Tło. Zagadnienie wzrostu gospodarczego jest wciąż ważnym obszarem badań ekonomicznych. Temat ten jest ważny dla nauk ekonomicznych, jak i również dla praktyki polityki gospodarczej. Najważniejszym założeniem w tym artykule niech będzie takie stwierdzenie: wszystko, co się dzieje w gospodarce, dotyczy zjawisk społeczno-gospodarczych. Główny problem naukowy sprowadza się do pytania - jaka jest rola czynników instytucjonalnych dla rozwoju społeczno-gospodarczego Polski?

Cele badawcze. Autor postawił sobie dwa główne cele. Pierwszym celem jest próba przedstawienia instytucjonalnych determinantów, które wpływają na rozwój społeczno-gospodarczy polskiej gospodarki. Drugi to próba przedstawienia rozwoju polskiej gospodarki na tle wybranych państw europejskich.

Metodologia. W pracy wykorzystano zmodyfikowaną metodę taksonomicznego miernika rozwoju bazująca na TOPSIS (Technique for Order Preference by Similarity to Ideal Solution). Badania zostały osadzone w nurcie nowej ekonomii instytucjonalnej. Wykorzystano także koncepcję matrycy instytucjonalnej.

Kluczowe wnioski. Prowadzone analizy pozwoliły na przedstawienie rozwoju społeczno-ekonomicznego polskiej gospodarki. Zostało to zobrazowane przeciętnym wskaźnikiem rozwoju społeczno-ekonomicznego (ASEDI). Skalkulowano także taksonomiczne mierniki rozwoju dla wszystkich 10 analizowanych gospodarek. Główny horyzont czasowy badań to lata 2008-2018. Część zebranych danych umożliwiła analizę w okresie 1995-2018. Na tej podstawie określono ranking państw ze względu na tempo rozwoju. Okazało się Polska, w 2018 roku, uplasowała się na 5 miejscu. Wyniki badań i analiz pozwoliły stwierdzić, że wybrane czynniki instytucjonalne w sposób istotny wpływaja na ostateczny poziom i jakość rozwoju społeczno-gospodarczego Polski w porównaniu z wybranymi krajami europejskimi.
\end{abstract}

Slowa kluczowe: rozwój gospodarczy, czynniki rozwoju, nowa ekonomia instytucjonalna, taksonomiczne mierniki rozwoju, dynamika społeczno-gospodarcza. 


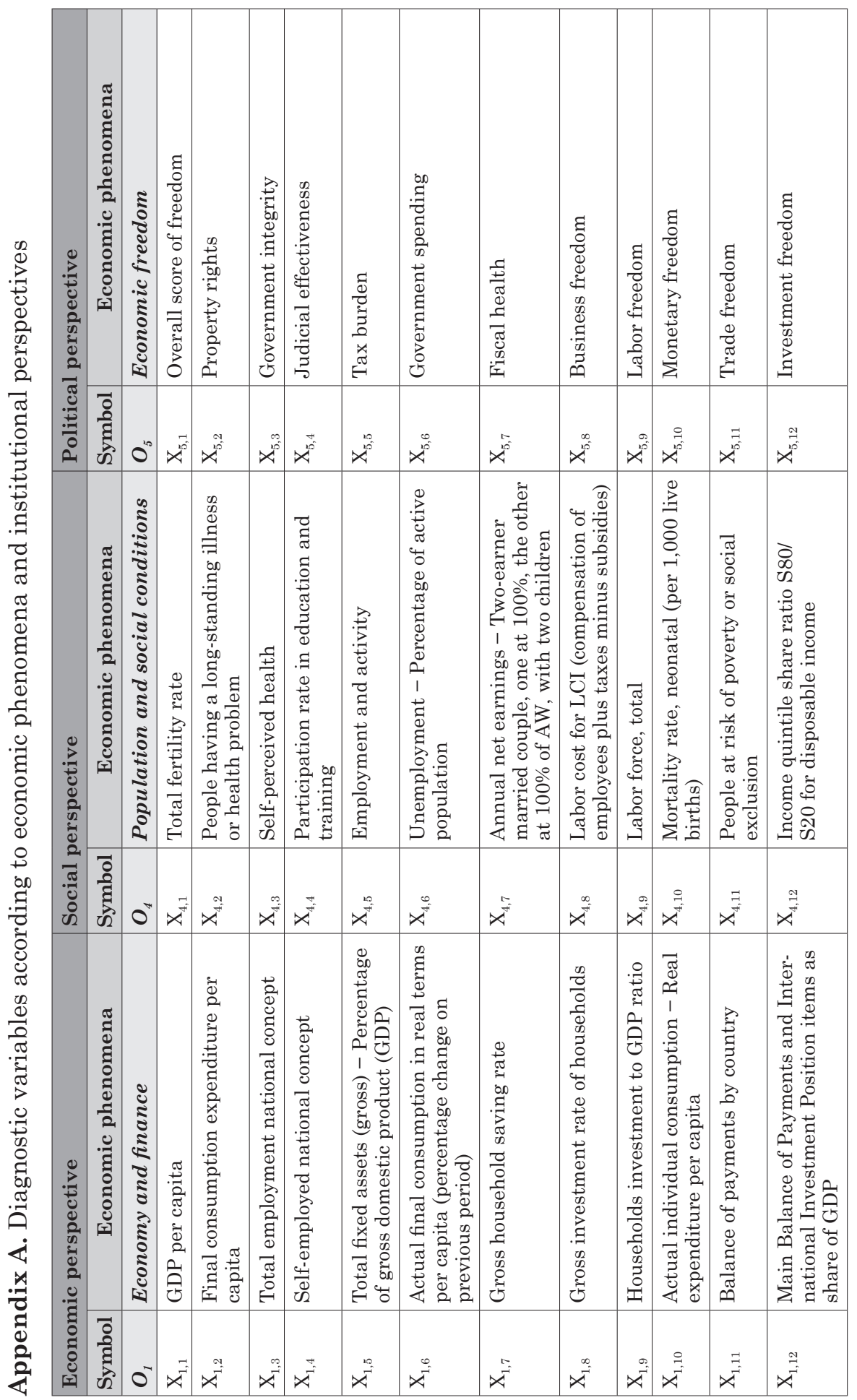




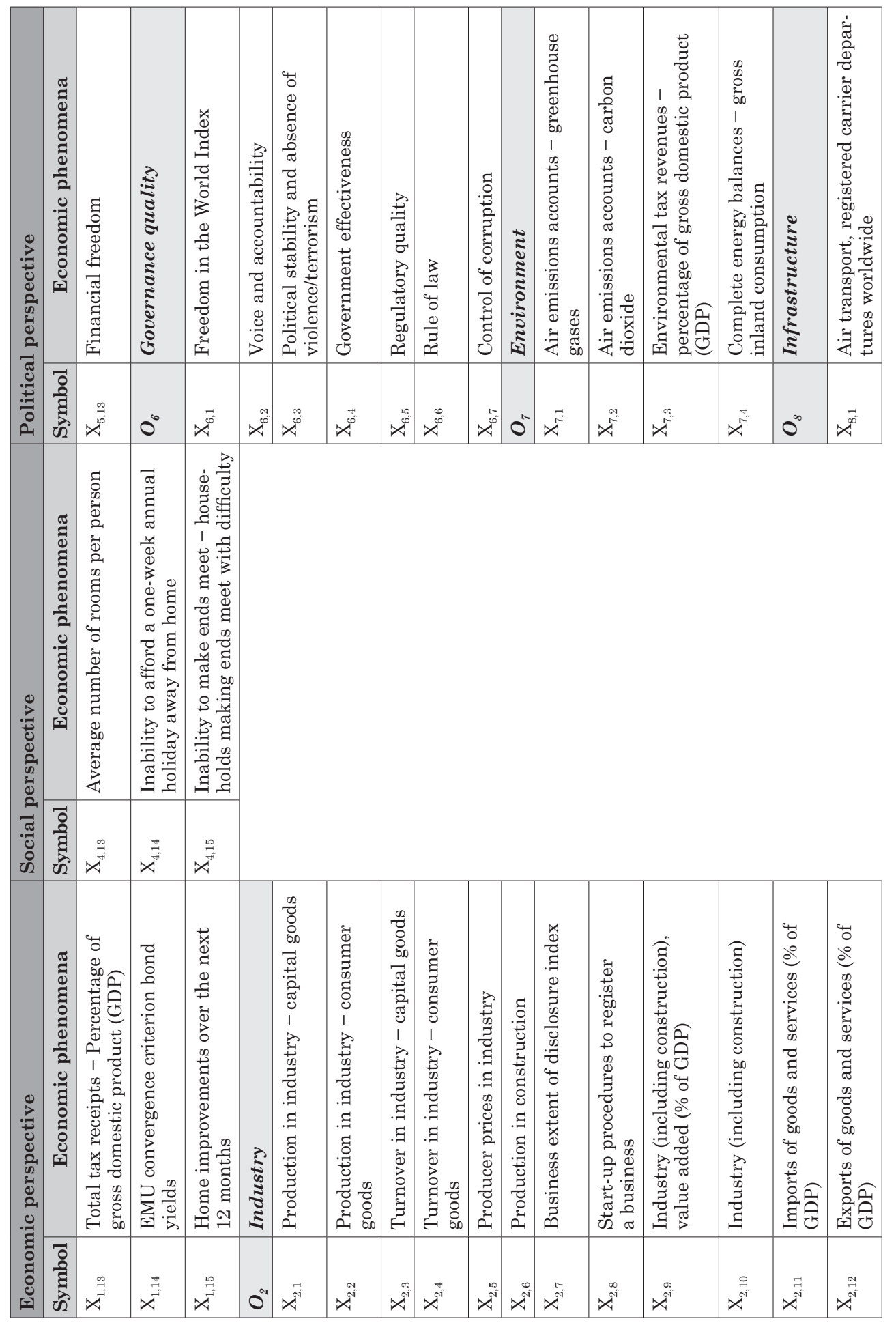




Appendix B. Taxonomic measure of development for economic phenomena

\begin{tabular}{|c|c|c|c|c|c|c|c|c|c|c|c|}
\hline Cour & 008 & 2009 & 2010 & 2011 & 2012 & 2013 & 2014 & 2015 & 2016 & 2017 & 2018 \\
\hline \multicolumn{12}{|c|}{ Economy and finance } \\
\hline Bulgaria & .279 & 0.181 & 0.237 & 0.280 & 0.245 & 0.199 & 0.296 & 0.274 & 0.296 & 0.233 & 0.268 \\
\hline Czech Republic & 0.295 & 0.222 & 0.227 & 0.229 & 0.234 & 0.237 & 0.266 & 0.282 & 0.294 & 0.316 & 0.301 \\
\hline France & 0.556 & 0.486 & 0.516 & 0.483 & 0.473 & 0.493 & 0.495 & 0.501 & 0.500 & 0.495 & 0.482 \\
\hline Germany & 0.673 & 0.699 & 0.755 & 0.751 & 0.747 & 0.731 & 0.751 & 0.740 & 0.749 & 0.731 & 0.728 \\
\hline Hungary & 0.213 & 0.221 & 0.271 & 0.217 & 0.266 & 0.272 & 0.318 & 0.330 & 0.358 & 0.343 & 0.294 \\
\hline Latvia & 0.261 & 0.338 & 0.316 & 0.293 & 0.292 & 0.361 & 0.183 & 0.232 & 0.216 & 0.264 & 0.276 \\
\hline Lithuania & 0.280 & 0.309 & 0.236 & 0.309 & 0.259 & 0.328 & 0.347 & 0.272 & 0.274 & 0.269 & 0.265 \\
\hline Poland & 0.461 & 0.346 & 0.399 & 0.355 & 0.331 & 0.343 & 0.380 & 0.393 & 0.410 & 0.426 & 0.408 \\
\hline Slovakia & 338 & 0.158 & 0.183 & 0.192 & 0.210 & 0.223 & 0.233 & 0.220 & 0.229 & 0.250 & 0.309 \\
\hline Spain & 466 & 0.382 & 0.374 & 0.373 & 0.387 & 0.402 & 0.441 & 0.463 & 0.466 & 0.464 & 0.433 \\
\hline $\mathrm{AVG}$ & 0.382 & 0.334 & 0.352 & 0.348 & 0.344 & 0.359 & 0.371 & 0.371 & 0.379 & 0.379 & 0.376 \\
\hline \multicolumn{12}{|c|}{ Industry } \\
\hline Bulgaria & 0.417 & 0.341 & 0.357 & 0.361 & 0.327 & 0.391 & 0.391 & 0.426 & 0.443 & 0.347 & 0.376 \\
\hline Czech Republic & 0.391 & 0.379 & 0.424 & 0.394 & 0.410 & 0.401 & 0.509 & 0.429 & 0.462 & 0.464 & 0.452 \\
\hline France & 0 & 77 & 0.527 & 0.538 & 0.521 & 0.503 & 46 & 78 & 0.512 & .556 & 0.538 \\
\hline & & 0.637 & & 0.772 & 0.702 & 0.710 & & & 0.712 & 0.763 & 0.732 \\
\hline Hungary & 0.490 & 0.321 & 0.383 & 0.404 & 0.378 & 0.359 & 51 & 0.452 & 0.521 & 405 & 0.319 \\
\hline Latvia & 0.435 & 0.346 & 0.345 & 0.422 & 0.445 & 0.401 & 0.339 & 0.341 & 0.364 & 0.381 & 0.365 \\
\hline Lithuania & 0.390 & 0.360 & 0.382 & 0.459 & 0.428 & 0.486 & 0.472 & 0.426 & 0.409 & 0.413 & 0.417 \\
\hline Poland & 0.444 & 0.444 & 0.478 & 0.448 & 0.417 & 0.416 & 0.533 & 0.489 & 0.490 & 0.486 & 0.447 \\
\hline \begin{tabular}{|l|} 
Slovakia \\
\end{tabular} & 0.503 & 0.358 & 0.457 & 0.404 & 0.430 & 0.379 & 0.413 & 0.452 & 0.416 & 0.384 & 0.401 \\
\hline Spain & 0.510 & 0.439 & 0.498 & 0.468 & 0.449 & 0.541 & 0.608 & 0.530 & 0.556 & 0.424 & 0.468 \\
\hline AVG & .471 & 0.410 & 0.460 & 0.467 & 0.451 & 0.459 & 0.494 & 0.482 & 0.489 & 0.462 & 0.452 \\
\hline \multicolumn{12}{|c|}{ Science and technology } \\
\hline Bulgaria & 0.307 & 0.306 & 0.296 & 0.293 & 0.295 & 0.295 & 0.299 & 0.310 & 0.303 & 0.302 & 0.301 \\
\hline Czech Republic & 0.396 & 0.393 & 0.384 & 0.405 & 0.410 & 0.421 & 0.427 & 0.421 & 0.420 & 0.418 & 0.418 \\
\hline France & 0.550 & 0.560 & 0.515 & 0.511 & 0.510 & 0.513 & 0.506 & 0.496 & 0.499 & 0.495 & 0.508 \\
\hline Germany & 0.678 & 0.678 & 0.709 & 0.701 & 0.698 & 0.686 & 0.676 & 0.711 & 0.690 & 0.681 & 0.658 \\
\hline Hungary & 0.350 & 0.366 & 0.352 & 0.351 & 0.345 & 0.357 & 0.350 & 0.324 & 0.341 & 0.348 & 0.364 \\
\hline Latvia & 0.308 & 0.303 & 0.297 & 0.295 & 0.297 & 0.303 & 0.310 & 0.317 & 0.304 & 0.308 & 0.309 \\
\hline Lithuania & 0.334 & 0.328 & 0.327 & 0.318 & 0.319 & 0.310 & 0.313 & 0.317 & 0.315 & 0.318 & 0.315 \\
\hline Poland & 0.284 & 0.283 & 0.263 & 0.267 & 0.265 & 0.280 & 0.292 & 0.309 & 0.310 & 0.309 & 0.310 \\
\hline Slovakia & 0.303 & 0.303 & 0.309 & 0.322 & 0.315 & 0.323 & 0.316 & 0.333 & 0.319 & 0.328 & 0.323 \\
\hline Spain & 0.485 & 0.469 & 0.428 & 0.416 & 0.416 & 0.347 & 0.358 & 0.354 & 0.358 & 0.354 & 0.342 \\
\hline AVG & 0.400 & 0.399 & 0.388 & 0.388 & 0.387 & 0.384 & 0.385 & 0.389 & 0.386 & 0.386 & 0.385 \\
\hline
\end{tabular}




\begin{tabular}{|c|c|c|c|c|c|c|c|c|c|c|c|}
\hline Cou & 008 & 2009 & 2010 & 2011 & 2012 & 2013 & 2014 & 2015 & 2016 & 2017 & 2018 \\
\hline \multicolumn{12}{|c|}{ Population and social conditions } \\
\hline Bulgaria & 0.264 & 0.287 & 0.263 & 0.246 & 0.288 & 0.236 & 0.239 & 0.251 & 0.262 & 0.262 & 0.303 \\
\hline Czech Republic & 0.420 & 0.408 & 0.415 & 0.429 & 0.416 & 0.441 & 0.408 & 0.393 & 0.404 & 0.403 & 0.410 \\
\hline France & 0.689 & 0.708 & 0.706 & 0.699 & 0.704 & 0.758 & 0.751 & 0.738 & 0.721 & 0.714 & 0.694 \\
\hline Germany & 0.823 & 0.844 & 0.876 & 0.833 & 0.796 & 0.857 & 0.830 & 0.835 & 0.847 & 0.849 & 0.850 \\
\hline Hungary & 0.326 & 0.399 & 0.427 & 0.290 & 0.271 & 0.330 & 0.343 & 0.345 & 0.343 & 0.332 & 0.340 \\
\hline Latvia & 0.234 & 0.387 & 0.433 & 0.218 & 0.235 & 0.247 & 0.247 & 0.246 & 0.251 & 0.268 & 0.237 \\
\hline Lithuania & 0.289 & 0.423 & 0.437 & 0.283 & 0.262 & 0.259 & 0.293 & 0.281 & 0.266 & 0.278 & 0.276 \\
\hline Poland & 0.429 & 0.430 & 0.450 & 0.424 & 0.440 & 0.439 & 0.450 & 0.453 & 0.449 & 0.465 & 0.468 \\
\hline Slovakia & 323 & 0.305 & 0.315 & 0.303 & 0.302 & 0.294 & 0.258 & 0.304 & 0.306 & 0.306 & 0.314 \\
\hline Spain & 577 & 0.529 & 0.595 & 0.552 & 0.555 & 0.521 & 0.513 & 0.508 & 0.508 & 0.509 & 0.497 \\
\hline AVG & 437 & 0.472 & 0.492 & 0.428 & 0.427 & 0.438 & 0.433 & 0.435 & 0.436 & 0.439 & 0.439 \\
\hline \multicolumn{12}{|c|}{ Economic Freedom } \\
\hline Bulgaria & 0.537 & 0.559 & 0.497 & 0.551 & 0.566 & 0.560 & 0.569 & 0.574 & 0.559 & 0.577 & 0.587 \\
\hline Czech Rep & 0.572 & 0.599 & 0. & 13 & 0.613 & 0.603 & 21 & 0. & 0.645 & 61 & .691 \\
\hline France & 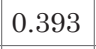 & 0.380 & 0. & 0. & 0.324 & 31 & 18 & 0.299 & 0.285 & 51 & .361 \\
\hline & 10 & 37 & & & & 12 & & & 0.643 & 364 & 687 \\
\hline Hungary & 167 & 0.420 & 0.432 & 0.443 & 0.481 & 0.463 & 46 & 0.428 & 0.414 & 0.424 & 0.452 \\
\hline Latvia & 33 & 0.610 & 0.591 & 0.563 & 0.555 & 0.563 & 0.596 & 0.622 & 0.639 & 0.758 & 0.687 \\
\hline Lithuania & 0.673 & 0.658 & 0.659 & 0.663 & 0.671 & 0.670 & 0.688 & 0.731 & 0.746 & 0.793 & 0.750 \\
\hline Poland & 0.428 & 0.430 & 0.498 & 0.500 & 0.552 & 0.546 & 0.557 & 0.596 & 0.601 & 0.584 & 0.589 \\
\hline Slovakia & 0.634 & 0.648 & 0.672 & 0.640 & 0.600 & 0.609 & 0.562 & 0.568 & 0.541 & 0.503 & 0.484 \\
\hline Spain & 0.652 & 0.660 & 0.641 & 0.627 & 0.607 & 0.565 & 0.523 & 0.503 & 0.529 & 0.439 & 0.475 \\
\hline AVG & .556 & 0.555 & 0.561 & 0.561 & 0.557 & 0.552 & 0.550 & 0.555 & 0.560 & 0.575 & 0.576 \\
\hline \multicolumn{12}{|c|}{ Governance Quality } \\
\hline Bulgaria & 0.116 & 0.098 & 0.091 & 0.073 & 0.085 & 0.047 & 0.055 & 0.056 & 0.032 & 0.083 & 0.116 \\
\hline Czech Republic & 0.468 & 0.475 & 0.462 & 0.488 & 0.458 & 0.452 & 0.483 & 0.507 & 0.520 & 0.544 & 0.528 \\
\hline France & 0.698 & 0.701 & 0.728 & 0.706 & 0.683 & 0.663 & 0.628 & 0.595 & 0.569 & 0.627 & 0.612 \\
\hline Germany & 0.849 & 0.859 & 0.826 & 0.839 & 0.832 & 0.868 & 0.906 & 0.854 & 0.862 & 0.827 & 0.844 \\
\hline Hungary & 0.421 & 0.372 & 0.365 & 0.378 & 0.328 & 0.331 & 0.258 & 0.272 & 0.248 & 0.289 & 0.279 \\
\hline Latvia & 0.279 & 0.305 & 0.319 & 0.296 & 0.327 & 0.359 & 0.390 & 0.392 & 0.413 & 0.420 & 0.402 \\
\hline Lithuania & 0.331 & 0.341 & 0.376 & 0.357 & 0.415 & 0.443 & 0.467 & 0.514 & 0.541 & 0.495 & 0.483 \\
\hline Poland & 0.365 & 0.409 & 0.428 & 0.452 & 0.472 & 0.460 & 0.474 & 0.477 & 0.402 & 0.373 & 0.355 \\
\hline Slovakia & 0.422 & 0.392 & 0.400 & 0.399 & 0.383 & 0.367 & 0.382 & 0.360 & 0.378 & 0.388 & 0.368 \\
\hline Spain & 0.485 & 0.464 & 0.477 & 0.508 & 0.490 & 0.464 & 0.412 & 0.408 & 0.440 & 0.417 & 0.431 \\
\hline $\mathrm{AVG}$ & 0.443 & 0.442 & 0.447 & 0.450 & 0.447 & 0.445 & 0.446 & 0.443 & 0.440 & 0.446 & 0.442 \\
\hline
\end{tabular}




\begin{tabular}{|c|c|c|c|c|c|c|c|c|c|c|c|}
\hline Country & 008 & 009 & 2010 & 2011 & 2012 & 2013 & 2014 & 2015 & 2016 & 2017 & 018 \\
\hline \multicolumn{12}{|c|}{ Environment } \\
\hline Bulgaria & 616 & 0.614 & 0.612 & 0.611 & 0.613 & 0.615 & 0.614 & 0.615 & 0.614 & 0.613 & 615 \\
\hline Czech Rep & 0.603 & 0.603 & 0.604 & 0.605 & 0.606 & 0.606 & 0.604 & 0.604 & 0.603 & 0.605 & .604 \\
\hline France & 0.623 & 0.621 & 0.623 & 0.636 & 0.639 & 0.637 & 0.648 & 0.650 & 0.651 & 0.649 & 0.657 \\
\hline German & 388 & 0.387 & 0.385 & 0.382 & 0.381 & 0.381 & 0.379 & 0.378 & 0.379 & 0.381 & 0.381 \\
\hline Hungary & 620 & 0.620 & 0.620 & 0.619 & 0.620 & 0.618 & 0.618 & 0.617 & 0.618 & 0.618 & 0.616 \\
\hline Latvia & 11 & 616 & 0.618 & 0.618 & 0.618 & .619 & 0.620 & 0.620 & 0.620 & 0.620 & 0.619 \\
\hline Lithuania & - & 0.610 & 0.606 & 0.604 & 0.604 & .604 & 0.604 & 0.605 & 0.605 & 0.605 & 0.606 \\
\hline Poland & 505 & 0.494 & 0.496 & 0.490 & 0.496 & 0.496 & 0.497 & 0.495 & 0.491 & 0.479 & 0.468 \\
\hline Slovakia & 0.610 & 0.609 & 0.610 & 0.613 & 0.613 & 0.614 & 0.614 & 0.613 & 0.614 & 0.615 & 0.614 \\
\hline Spain & 544 & 0.551 & 0.566 & 0.560 & 0.561 & 0.581 & 0.573 & 0.562 & 0.576 & 0.568 & 0.568 \\
\hline 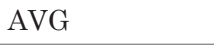 & 572 & 0.572 & 0.574 & 0.574 & 0.575 & 0.577 & 0.577 & 0.576 & 0.577 & 0.575 & 0.575 \\
\hline \multicolumn{12}{|c|}{ Infrastructure } \\
\hline & ( & & 0.387 & 0.403 & 0.404 & 0.406 & & 0.407 & 0.410 & 0.423 & 0.418 \\
\hline Czech R & 0.377 & 9 & 0.371 & 0.371 & 71 & 0 & 88 & 75 & 93 & 83 & .386 \\
\hline & 0.747 & 0. & 0.732 & 0.722 & 0.729 & 77 & 88 & 0.676 & 0.677 & 0.666 & .665 \\
\hline Germ & 0.518 & 0.551 & 0.529 & 0.533 & 0.532 & 0.548 & 0.547 & 0.547 & 0.540 & 0.536 & 0.532 \\
\hline Hungary & 0.407 & 0.412 & 0.406 & 0.406 & 0.403 & 0.410 & 0.414 & 0.417 & 0.409 & 0.413 & 0.417 \\
\hline Latvia & 0.413 & 0.415 & 0.409 & 0.409 & 0.410 & 0.410 & 0.410 & 0.409 & 0.407 & 0.409 & 0.409 \\
\hline Lithuania & 0.423 & 0.424 & 0.412 & 0.412 & 0.413 & 0.415 & 0.414 & 0.414 & 0.414 & 0.414 & 0.413 \\
\hline Poland & 0.275 & 0.308 & 0.266 & 0.267 & 0.273 & 0.294 & 0.290 & 0.285 & 0.288 & 0.295 & 0.301 \\
\hline Slovakia & 0.414 & 0.417 & 0.401 & 0.403 & 0.403 & 0.404 & 0.404 & 0.405 & 0.405 & 0.404 & 0.405 \\
\hline Spain & 0.601 & 0.600 & 0.622 & 0.609 & 0.598 & 0.603 & 0.612 & 0.626 & 0.631 & 0.637 & 0.652 \\
\hline AVG & 0.457 & 0.455 & 0.454 & 0.453 & 0.454 & 0.455 & 0.455 & 0.456 & 0.457 & 0.458 & 0.460 \\
\hline
\end{tabular}

